\title{
Influence of Integrated Nutrient Management on Growth and Tuber Yield of Potato (Solanum tuberosum L.) Crop under Heavy Soils of Punjab
}

\author{
Pardeep Singh* and Harpreet Kaur
}

Campus for Research and Advanced Studies Dhablan, General Shivdev Singh Diwan

Gurbachan Singh, Khalsa College Patiala, 147001

*Corresponding author

\section{A B S T R A C T}

Keywords

Potato, integrated

nutrient

management, Farm

yard manure,

Vermicompost,

Azotobacter,

Phosphorus

solubilizing bacteria

Article Info

Accepted:

12 May 2021

Available Online:

10 June 2021
The present experimental field work was conducted during the year 20192020 at Campus for Research and Advanced Studies, Dhablan, G.S.S.D.G.S Khalsa College, Patiala. The different sources of fertilizers, organic manures and biofertilizers were integrated into 11 possible treatments. All the treatments have helped in the improvement of growth and tuber yield characteristics. Out of these treatments, where fertilizers have acted as integrated sources of nutrients were significantly registered as maximum effect. Highest plant height $(43.76 \mathrm{~cm})$, fresh weight of plant (106.94 g), number of leaves (72.00) and tuber yield (201.15 $\left.\mathrm{q} \mathrm{ha}^{-1}\right)$ in potato were recorded in the treatment $75 \% \mathrm{RDF}+$ Azotobacter $+\mathrm{PSB}$, while the lowest was observed in the control plot. The economics of this experiment was also observed highest under $75 \% \mathrm{RDF}+$ Azotobacter + PSB as compared to other treatments. Hence, we concluded that the treatment $75 \% \mathrm{RDF}+$ Azotobacter + PSB is suitable for the soils of Patiala for attaining good yield and productivity.

\section{Introduction}

Potato is a major staple food fulfilling human nutritional requirements. Worldwide, the potato comes forth in terms of production after wheat, maize, and rice. In many countries, potato serves as their staple food because of its excellent nutritional content. Potato (Solanum tuberosum L.) belongs to the family
Solanaceae and genus Solanum. The origin of the potato can be traced to the highlands of the Peruvian Andes-mountains in South America (Rykaczewska 2013). Potatoes are being grown in about 150 countries throughout the world and more than a billion of people worldwide eat potato. China covers highest area under potato in world and followed by India (Scott and Suarez 2011). Russian 
federation is third in area and production. In India, potato is an important vegetable crop and occupies splendid position among food crops. The cultivation of potato on large scale was begun first in the Nilgiris hills in 1822, thereafter; it spread all over the country. In Punjab, the total area under potato production is 96.57 thousand ha with total production of about 2518.95 million $t$ (Anonymous 2019). Modern nutrient management strategy has shifted its focus towards the concept of sustainability and eco-friendly environment in the soil. Excess use of chemical fertilizers to obtain high yield has created various problems like deterioration of soil health in terms of physical and chemical properties of soil, ceased microbial activities and increased soil pollution. Hence, considering the economy, environment and maintain better soil health, it is imperative that plant nutrients are to be used effectively by adopting integrated nutrient management practices (Shubha et al., 2018).

\section{Materials and Methods}

The field experiment was laid out in randomized block design with 11 different treatments by 3 replications. The soil of experimental field was clay, having $\mathrm{pH} 7.8$, medium in organic carbon $(0.60 \%)$, low in available nitrogen $\left(262.62 \mathrm{~kg} \mathrm{ha}{ }^{-1}\right)$ and medium in available phosphorus $\left(22.32 \mathrm{~kg} \mathrm{ha}^{-}\right.$ ${ }^{1}$ ) and potassium (130 $\left.\mathrm{kg} \mathrm{ha}^{-1}\right)$.

All the nutrients were applied as basal dose at one day before sowing. Kufri Chipsona-1 as per treatment was sown on 18 November, 2019 and harvested at 28 February, 2020. The crop was planted maintaining a distance of 60 $\mathrm{cm}$ and $20 \mathrm{~cm}$ between the row and plants respectively. Five representative sample plants were randomly selected from each of the plots for plant height was recorded in $\mathrm{cm}$. The numbers of leaves plant ${ }^{-1}$ were counted from the five randomly selected sample plants and the values of these were summed up and average was calculated. To study the fresh weight, five plants were collected from the sampling rows of each plot at 30 days interval from sowing till harvest of the crop. The plant samples were then weighted to record the average fresh weight, number of leaves, plant height and tuber yield.

\section{Results and Discussion}

The maximum plant height (24.66, 38.88 and $43.76 \mathrm{~cm}$ respectively) was reported at 30,60 and 90 DAS with the application of $75 \%$ RDF +FYM@6 t ha ${ }^{-1}+$ Vermicompost @ $2 \mathrm{t} \mathrm{ha}^{-1}$ + Azotobacter + PSB $\left(\mathrm{T}_{11}\right)$. Minimum plant height (14.36, 28.69 and $32.54 \mathrm{~cm}$ respectively) was reported in $\mathrm{T}_{1}$ : control.

This might be due to integration of inorganic fertilizers and biofertilizers because biofertilizer fix atmospheric nitrogen in soils and phosphorus which assimilate more photosynthates to ehnace the vegetative growth of plant. Similar result was recorded by Bhaishya et al., (2013). The maximum fresh weight plant ${ }^{-1}$ (41.64, 87.78 and 106.94 g respectively) was recorded at 30, 60 and 90 DAS with the application of 75\% RDF + FYM @ $6 \mathrm{t} \mathrm{ha}^{-1}+$ Vermicompost @ $2 \mathrm{t} \mathrm{ha}^{-1}+$ Azotobacter + PSB $\left(\mathrm{T}_{11}\right)$.

The lowest fresh weight per plant was noticed in $\mathrm{T}_{1}$ : control $(25.75,53.25$ and $80.27 \mathrm{~g})$. The fresh weight plant is due to better supply of nutrients, better root and shoots development secrete phytohormone and improve uptake of essential nutrients in presence of organic manure because the application of PSB makes phosphorus in available form in soil. Similar results have been reported by Kumar et al., (2001) and Dash and Jena (2015). Maximum number of leaves plant ${ }^{-1}(41.16,66.56,72.00)$ was observed at 30,60 and 90DAS in $\mathrm{T}_{11}$ : $75 \%$ RDF+FYM @ $6 \mathrm{t} \mathrm{ha}^{-1}+$ Vermicompost @ $2 \mathrm{t} \mathrm{ha}^{-1}+$ Azotobacter + PSB. Less number of leaves per plants was found in $\mathrm{T}_{1}$ : Control $(24.49,43.90,50.87)$. 
Table.1 Influence of intergrated nutrient management on plant height (cm) of potato (Solanum tuberosum L.) cv. Kufri Chipsona - 1 .

\begin{tabular}{|c|c|c|c|}
\hline \multirow[t]{2}{*}{ Treatments } & \multicolumn{3}{|c|}{ Plant height (cm) } \\
\hline & 30 DAS & 60 DAS & 90 DAS \\
\hline $\mathbf{T}_{1}$ : Control & 14.36 & 28.69 & 32.54 \\
\hline $\mathrm{T}_{2}: 100 \% \mathrm{RDF}$ & 22.91 & 36.76 & 40.92 \\
\hline $\mathrm{T}_{3}: \mathbf{7 5 \%} \mathrm{RDF}$ & 18.63 & 32.33 & 36.16 \\
\hline $\mathrm{T}_{4}: \mathbf{5 0 \%} \mathrm{RDF}$ & 17.56 & 31.64 & 35.63 \\
\hline $\mathrm{T}_{5}:$ FYM @ $12 \mathrm{t} \mathrm{ha}^{-1}$ & 15.46 & 29.63 & 33.81 \\
\hline $\mathrm{T}_{6}:$ Vermicompost @ $4 \mathrm{t} \mathrm{ha}^{-1}$ & 16.43 & 30.43 & 34.63 \\
\hline $\mathrm{T}_{7}: 75 \% \mathrm{RDF}+\mathrm{FYM} @ 6 \mathrm{tha}^{-1}$ & 19.82 & 33.59 & 37.33 \\
\hline $\mathrm{T}_{8}: 75 \%$ RDF + Vermicompost @ $2 \mathrm{tha}^{-1}$ & 20.40 & 34.72 & 38.16 \\
\hline T9: $_{9}$ 75\% RDF + Azotobacter + PSB & 23.58 & 37.46 & 41.53 \\
\hline $\begin{array}{l}\text { T10:75\% RDF+FYM @6 tha } \text { h }^{-1}+\text { Vermicompost @ } 2 \mathrm{t} \\
\text { ha }^{-1}\end{array}$ & 21.56 & 35.43 & 39.65 \\
\hline $\begin{array}{l}\text { T}_{11}: 75 \% \text { RDF + FYM @ } 6 \mathrm{t} \mathrm{ha}^{-1}+\text { Vermicompost @ } 2 \mathrm{t} \\
\mathrm{ha}^{-1}+\text { Azotobacter + PSB }\end{array}$ & 24.66 & 38.88 & 43.76 \\
\hline $\mathrm{SE}(\mathrm{d}) \pm$ & 0.81 & 1.05 & 1.33 \\
\hline CD at 0.05 & 1.70 & 2.20 & 2.78 \\
\hline
\end{tabular}


Table.2 Influence of inorganic fertilizers and biofertilizer on the fresh weight (g) plant ${ }^{-1}$ of potato (Solanum tuberosum L.) cv. Kufri Chipsona -1 .

\begin{tabular}{|c|c|c|c|}
\hline \multirow[t]{2}{*}{ Treatments } & \multicolumn{3}{|c|}{ Fresh weight (gm) } \\
\hline & 30 DAS & 60 DAS & 90 DAS \\
\hline $\mathbf{T}_{1}$ : Control & 25.75 & 53.25 & 80.27 \\
\hline $\mathrm{T}_{3}: \mathbf{7 5 \%} \mathrm{RDF}$ & 31.21 & 68.45 & 90.63 \\
\hline $\mathrm{T}_{4}: \mathbf{5 0 \%} \mathrm{RDF}$ & 30.22 & 66.24 & 87.36 \\
\hline T$_{5}:$ FYM @12 t ha ${ }^{-1}$ & 26.96 & 57.55 & 82.78 \\
\hline $\mathrm{T}_{7}: 75 \% \mathrm{RDF}+\mathrm{FYM} @ 6 \mathrm{tha}^{-1}$ & 32.21 & 70.71 & 93.57 \\
\hline $\mathrm{T}_{8}: 75 \% \mathrm{RDF}+$ Vermicompost @ $2 \mathrm{t} \mathrm{ha}{ }^{-1}$ & 33.22 & 73.32 & 95.95 \\
\hline T $_{9}: 75 \%$ RDF + Azotobacter + PSB & 39.16 & 84.10 & 104.29 \\
\hline $\mathrm{T}_{10}: 75 \%$ RDF+FYM @6 tha $\mathrm{ha}^{-1}+$ Vermicompost @ $2 \mathrm{tha}^{-1}$ & 35.88 & 76.44 & 98.65 \\
\hline $\begin{array}{l}\mathrm{T}_{11}: 75 \% \mathrm{RDF}+\mathrm{FYM} @ 6 \mathrm{t} \mathrm{ha}^{-1}+\text { Vermicompost @ } 2 \mathrm{t} \mathrm{ha}^{-1}+ \\
\text { Azotobacter + PSB }\end{array}$ & 41.64 & 87.78 & 106.94 \\
\hline
\end{tabular}


Table.3 Influence of Integrated nutrient management on number of leaves in potato (Solanum tuberosum L.) cv. Kufri Chipsona - 1.

\begin{tabular}{|c|c|c|c|}
\hline \multirow[t]{2}{*}{ Treatments } & \multicolumn{3}{|c|}{ Number of leaves } \\
\hline & 30 DAS & 60 DAS & 90 DAS \\
\hline $\mathrm{T}_{1}$ : Control & 24.49 & 43.90 & 50.87 \\
\hline $\mathrm{T}_{2}: 100 \% \mathrm{RDF}$ & 36.98 & 61.83 & 69.83 \\
\hline $\mathrm{T}_{3}: \mathbf{7 5 \%} \mathrm{RDF}$ & 31.35 & 52.16 & 62.18 \\
\hline $\mathrm{T}_{4}: 50 \% \mathrm{RDF}$ & 29.42 & 49.12 & 57.08 \\
\hline T $_{5}:$ FYM @ 12 t ha $^{-1}$ & 26.04 & 46.52 & 54.25 \\
\hline $\mathrm{T}_{6}:$ Vermicompost @ $4 \mathrm{t} \mathrm{ha}^{-1}$ & 27.48 & 48.23 & 56.40 \\
\hline $\mathrm{T}_{7}: 75 \% \mathrm{RDF}+\mathrm{FYM} @ 6 \mathrm{tha}^{-1}$ & 32.19 & 56.56 & 65.39 \\
\hline $\mathrm{T}_{8}: 75 \% \mathrm{RDF}+$ Vermicompost @ $2 \mathrm{t} \mathrm{ha}^{-1}$ & 34.10 & 58.28 & 67.01 \\
\hline $\mathrm{T}_{9}: 75 \% \mathrm{RDF}+$ Azotobacter + PSB & 38.89 & 64.51 & 71.13 \\
\hline $\begin{array}{l}\text { T}_{10}: 75 \% \text { RDF+FYM @6 t ha } \\
\text { ha }^{-1}\end{array}$ & 35.48 & 59.67 & 68.66 \\
\hline $\begin{array}{l}\mathrm{T}_{11}: 75 \% \text { RDF + FYM @6 t ha } \mathrm{ha}^{-1}+\text { Vermicompost @ } 2 \mathrm{t} \\
\text { ha }^{-1}+\text { Azotobacter + PSB }\end{array}$ & 41.16 & 66.56 & 72.00 \\
\hline $\mathrm{SE}(\mathrm{d}) \pm$ & 1.02 & 1.06 & 1.08 \\
\hline CD at 0.05 & 3.53 & 3.68 & 3.75 \\
\hline
\end{tabular}


Table.4 Influence of INM on yield (q ha ${ }^{-1}$ ) of potato (Solanum tuberosum L.) cv. Kufri Chipsona-1.

\begin{tabular}{|c|c|}
\hline Treatments & Tuber yield $\left(\mathbf{q ~ h a}^{-1}\right)$ \\
\hline $\mathrm{T}_{1}$ : Control & 94.84 \\
\hline $\mathrm{T}_{2}: \mathbf{1 0 0 \%} \mathrm{RDF}$ & 191.96 \\
\hline $\mathrm{T}_{3}: \mathbf{7 5 \%} \mathrm{RDF}$ & 148.10 \\
\hline $\mathrm{T}_{4}: \mathbf{5 0 \%} \mathrm{RDF}$ & 135.75 \\
\hline T $_{5}:$ FYM @ $12 \mathrm{tha}^{-1}$ & 113.42 \\
\hline $\mathrm{T}_{6}:$ Vermicompost @ $4 \mathrm{t} \mathrm{ha}^{-1}$ & 121.32 \\
\hline $\mathrm{T}_{7}: 75 \%$ RDF + FYM @6t ha ${ }^{-1}$ & 153.45 \\
\hline $\mathrm{T}_{8}: 75 \% \mathrm{RDF}+$ Vermicompost @ $2 \mathrm{t} \mathrm{ha}^{-1}$ & 174.02 \\
\hline $\mathrm{T}_{9}: 75 \% \mathrm{RDF}+$ Azotobacter + PSB & 196.16 \\
\hline $\mathrm{T}_{10}: 75 \%$ RDF+FYM @ $6 \mathrm{tha}^{-1}+$ Vermicompost @ $2 \mathrm{t} \mathrm{ha}^{-1}$ & 179.14 \\
\hline $\mathrm{T}_{11}: 75 \%$ RDF + FYM @6 $\mathrm{t} \mathrm{ha}^{-1}+$ Vermicompost @ $2 \mathrm{t} \mathrm{ha}^{-1}+$ Azotobacter + PSB & 201.15 \\
\hline $\mathrm{SE}(\mathrm{d}) \pm$ & 3.99 \\
\hline CD at 0.05 & 8.33 \\
\hline
\end{tabular}


Fig.1 Influence of Integrated nutrient management on plant height $(\mathrm{cm})$ of potato (Solanum tuberosum L.) cv. Kufri Chipsona - 1

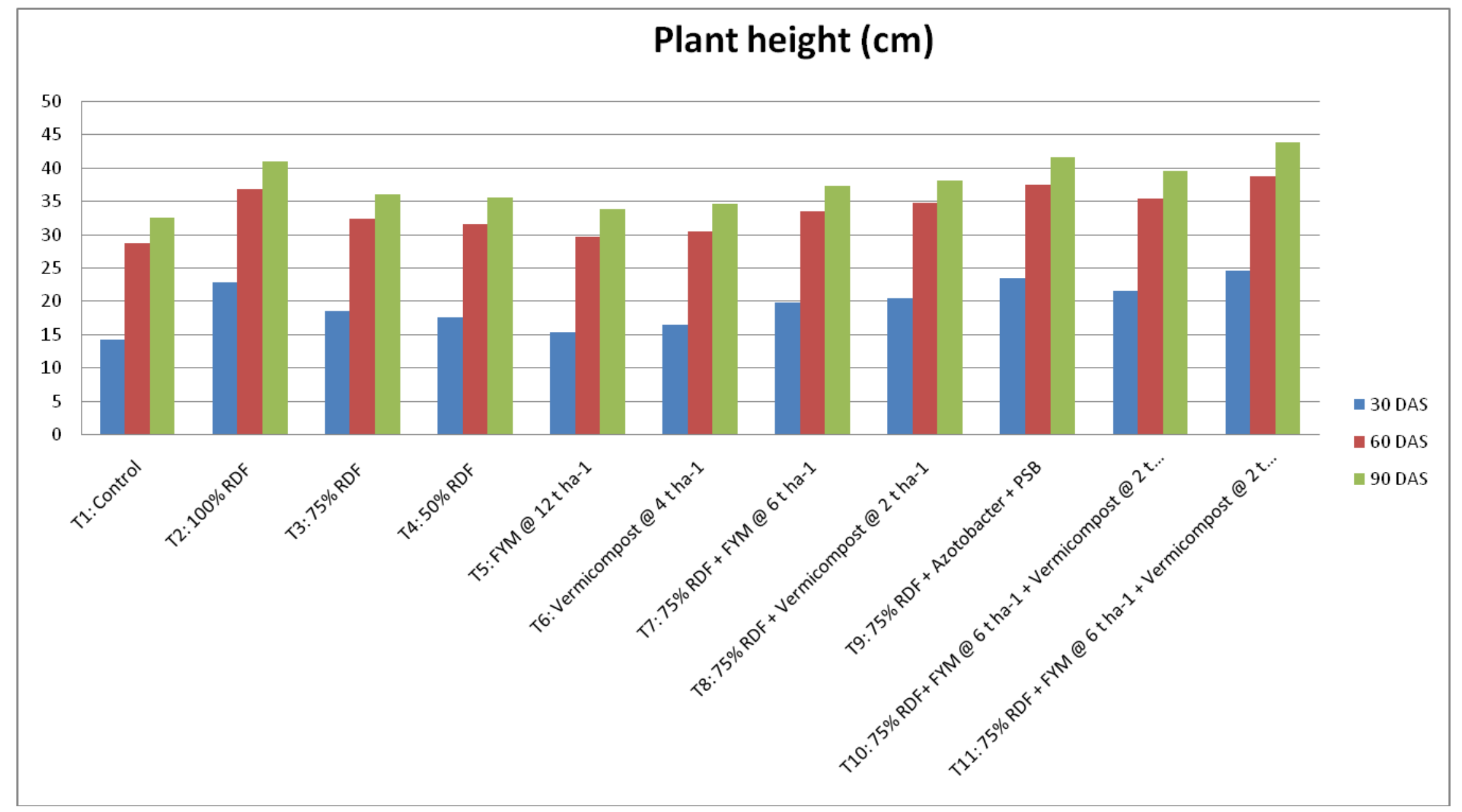


Fig.2 Influence of Integrated nutrient management on fresh weight (g) of potato (Solanum tuberosum L.) cv. Kufri chipsona - 1

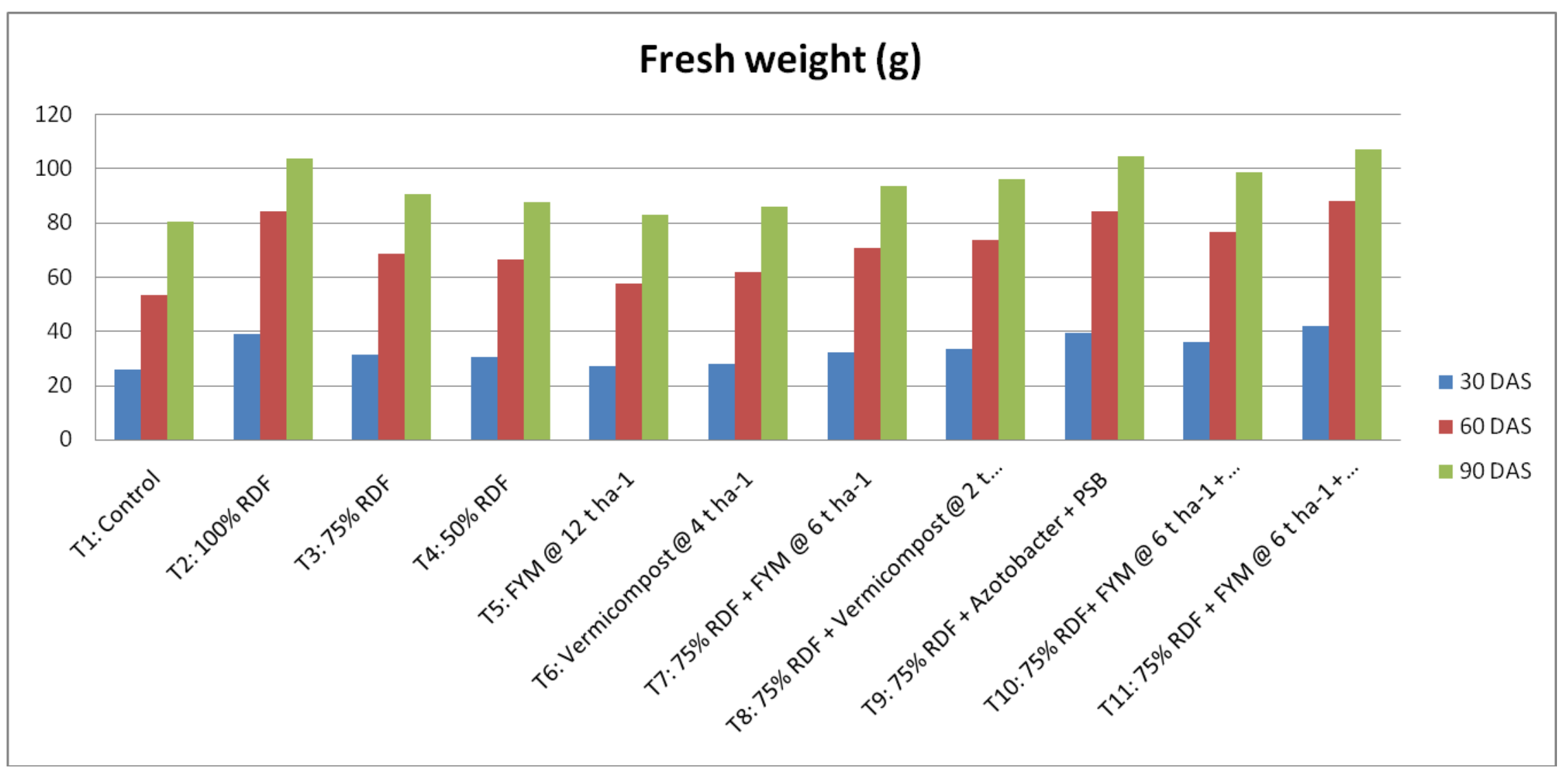


Fig.3 Influence of Integrated nutrient management on number of leaves in potato (Solanum tuberosum L.) cv. Kufri Chipsona - 1

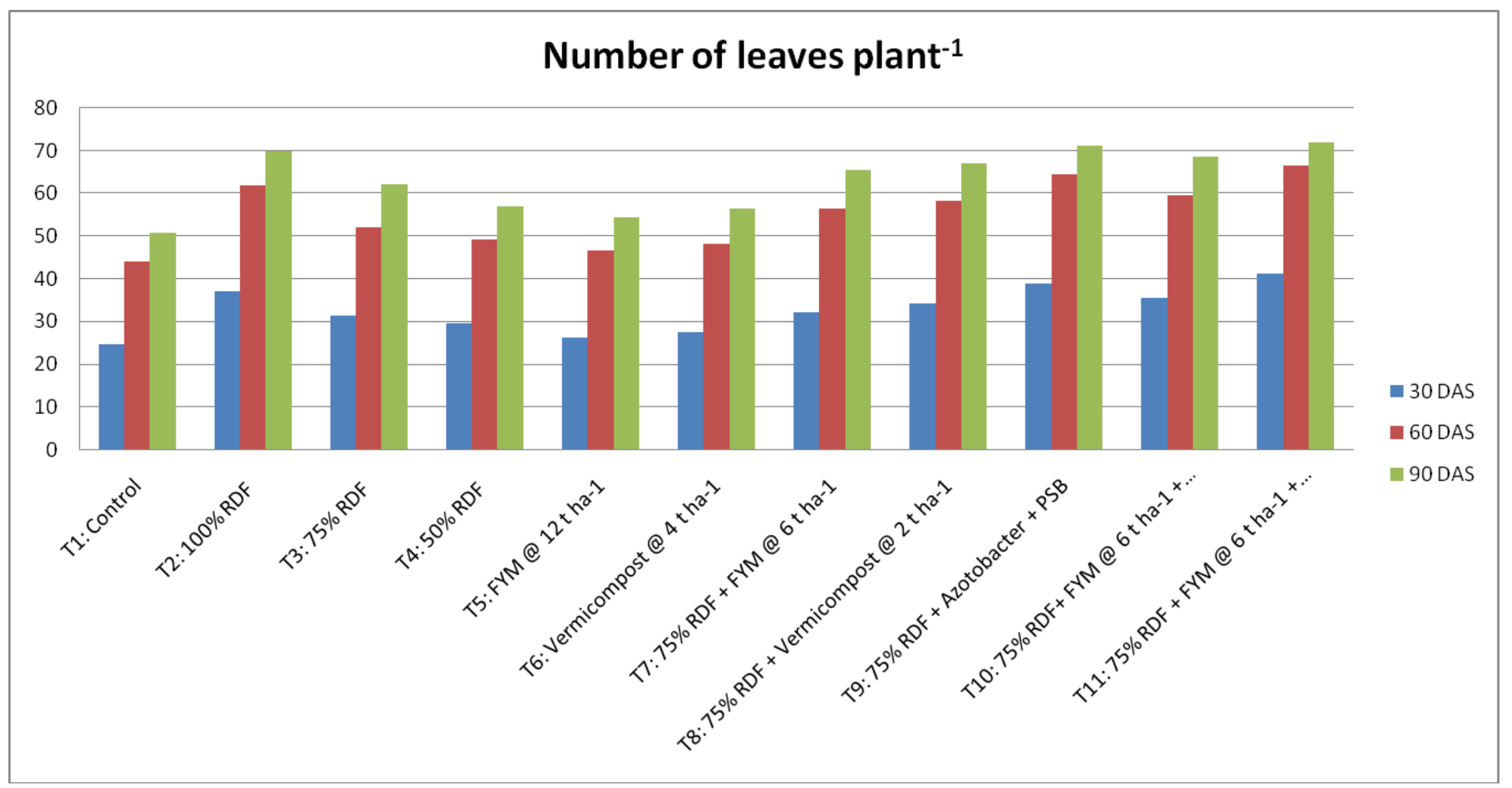


Fig.4 Influence of INM on yield ( $\mathrm{q} \mathrm{ha}^{-1}$ ) of potato (Solanum tuberosum L.) cv. Kufri Chipsona-1

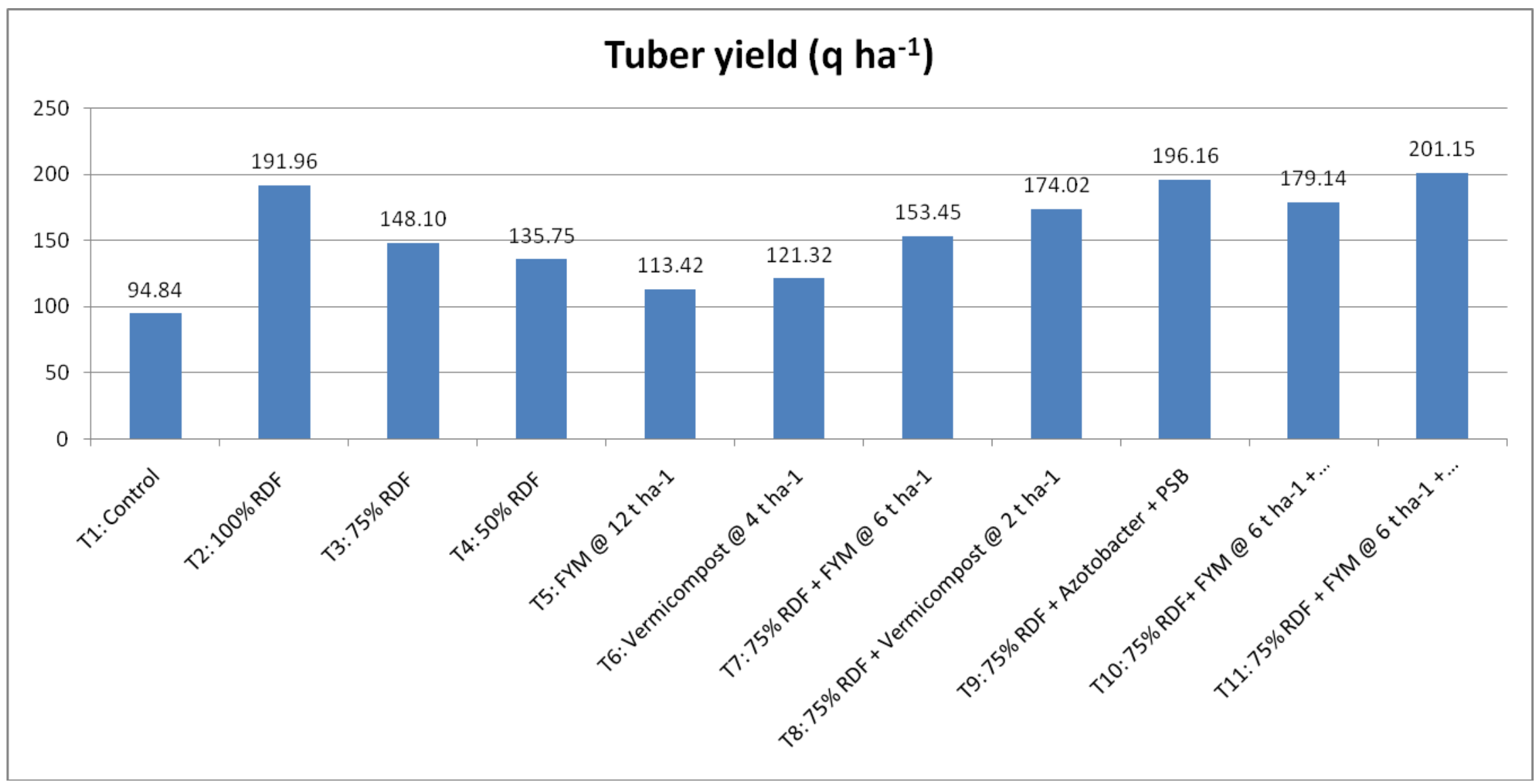


The positive and significant effect on nitrogen, phosphorous and potash along with FYM, Vermicompost and biofertilizers to enhance the vegetative growth of plant and soil properties due to better photosynthesis area has been studied by by Sahota and Govinda krishnan (1984) and Gupta and Pal (1989) and their findings also support present research study. The maximum yield (201.15 $\left.\mathrm{q} \mathrm{ha}^{-1}\right)$ was recorded in $\mathrm{T}_{11}: 75 \% \mathrm{RDF}+\mathrm{FYM} @ 6 \mathrm{t} \mathrm{ha}^{-1}$ +Vermicompost@2 t ha ${ }^{-1}+$ Azotobacter + PSB. While, minimum yield (94.84 $\mathrm{q} \mathrm{ha}^{-1}$ ) was recorded in $\mathrm{T}_{1}$ : Control. Tuber yield might be increased due to application of $75 \%$ RDF with organic manure and biofertilizers which leads to cell division and elongation that causes more photosynthesis and translocation of photosynthates to the tuber (Mulubrhan et al., 2004 and Zewide et al., 2012). Among biofertilizers, the dual application of biofertilizer was effective in increasing total tuber yield (Kumar and Mangal 1997). The results are commensurating with the present findings.

On the basis of the results from the present investigations, the following conclusions have been drawn, the parameters of potato like plant height $(43.76 \mathrm{~cm})$, fresh weight $(106.94$ $\mathrm{g}$ ), number of leaves (72.00) and tuber yield $\left(201.15 \mathrm{q} \mathrm{ha}^{-1}\right)$ in potato plant were reported highest under 75\% RDF + FYM @ $6 \mathrm{t} \mathrm{ha}^{-1}+$ Vermicompost@2 $\mathrm{t} \mathrm{ha}^{-1}+$ Azotobacter + PSB which is statistically at par with $75 \%$ $\mathrm{RDF}+$ Azotobacter + PSB .

\section{References}

Anonymous. 2019. Statewise Area and Production of Potato (At Current and Constant Production). Hortiicultural Statistics at a Glance. Pp: 151-213.

Baishya L K, Gupta V K, Lal S S, Das B K and Kumar M. 2013. Effect of biofertilizers on growth and yield of potato in northeastern hills of India. Journal of Potato. 3(2): 3-4.

Dash S N and Jena R C. 2015. Biofertilizers options in nutrient management of potato. International Journal of Scientific Research. 4(1): 420-421.

Gupta A and Pal K. 1989. Response of potato varieties to nitrogen fertilization under rainfed conditions. Indian Journal Agronomony. 34(4): 478-480.

Kumar V and Managal J L. 1997. Effect of salinity, phosphorus and VAM on growth and yield of potato $c v$. Kufri Badshah. Haryana Journal of Horticulture Sciences. 26(3-4): 247-250.

Kumar V. 2001. Effect of biofertilizers on growth and yield of potato. Journal of the Indian Potato Association. 28(1): 60-61.

Mulubrhan H. 2004. The effect of Nitrogen, Phosphorus and Potassium fertilization on the yield and yield components of potato (Solanum tuberosum L.) grown on vertisols of Mekele area. Journal of Horticultural Sciences. 7(1): 22-54.

Rykaczeewska K. 2013. The impact of high temperature during growing seasons on potato cultivar with different response to environmental stresses. American Journal of Plant Sciences. 4: 2386-2393.

Sahota T S and Govinda krishnan P M. 1984. Effect of soil and foliar application of $\mathrm{N}$ on potato at Shilling. Bangladesh Journal of Horticulture. 1(2): 1-9.

Scott G and Sauraze M. 2011. The rise of asia as the centre of global potato production and some implications for industry. Journal of Potato. 39(1): 1-22.

Shubha A S, Srinivasa V, Shanwaz A, Anusha R B and Sharavathi M B. 2018. Effect of Integrated Nutrient Management on Growth and Yield Attributes in Potato (Solanum tuberosum L.). International Journal of Current Microbiology and Applied Sciences. 7(9): 830-36.

Zewide I, Mohammed A and Tulu S. 2012. Effect of different rates of nitrogen and phosphorus on yield and yield components of potato (Solanum tuberosum L.). International Journal of Soil Sciences. 7: 146-56. 


\section{How to cite this article:}

Pardeep Singh and Harpreet Kaur. 2021. Influence of Integrated Nutrient Management on Growth and Tuber Yield of Potato (Solanum tuberosum L.) Crop under Heavy Soils of Punjab. Int.J.Curr.Microbiol.App.Sci. 10(06): 245-256. doi: https://doi.org/10.20546/ijcmas.2021.1006.026 